\title{
Effectiveness of Azadirachta indica A. Juss (Neem) Seed Oil in Controlling Wood Termite
}

\author{
${ }^{* 1}$ OKANLAWON, FB; ${ }^{1}$ ADEGOKE, OA; ${ }^{2}$ OLATUNJI, OA; ${ }^{1}$ OKON-AKAN, OA; \\ ${ }^{2}$ AKALA, AO \\ ${ }^{*}$ Department of Wood and Paper Technology, Federal College of Forestry, Ibadan, Nigeria \\ ${ }^{2}$ Department of Bioscience, Forestry Research Institute of Nigeria, Ibadan, Nigeria \\ *Corresponding Author Email: okanlawon.fb@gmail.com
}

\begin{abstract}
The protection of wood against biodeteriorating agents like termite during processing or in service has call for serious possible approach using new safer, environmental friendly preservatives hence this study therefore evaluated Azadirachta indica seed oil against termite attack on Gmelina arborea and Triplochiton scleroxylon wood. The seed oil was obtained using a soxhlet apparatus and N-hexane as the solvent. The wood was dimensioned into $20 \times 20 \times 20 \mathrm{~mm}$ and the seed oil was applied by brushing, dipping and soaking and exposed to termitarium while the absorption rate and weight loss to termite attack were determined. Data collected was analyzed using simple statistics and analysis of variance at $\alpha_{0.05}$. The antimicrobial properties of the need seed oil are due to the availability of phytochemicals which promote antimicrobial activity. The maximum wood protection against termite of all the methods of application was obtained from soaking. The absorption and weight loss ranged from $11.20-43.88 \%$ and $56.50-61.58 \%$ for G. arborea and T. scleroxylon respectively. However, all the application methods used for the wood treatment proved to be effective over the untreated wood.
\end{abstract}

\section{DOI: $\underline{\text { https://dx.doi.org/10.4314/jasem.v24i9.9 }}$}

Copyright: Copyright $(\mathcal{C} 2020$ Okanlawon et al. This is an open access article distributed under the Creative Commons Attribution License (CCL), which permits unrestricted use, distribution, and reproduction in any medium, provided the original work is properly cited.

Dates: Received: 25 August 2020; Revised: 25 September 2020; Accepted: 20 September 2020

Keywords: phytochemicals, seed oil, wood species, wood preservation, wood termite

The cause of wood deterioration during its processing or in service is of great concern to wood and environmental scientists. In recent time, the damage to wood has become so high in tropical region that the use of preservative treatment becomes compulsory. Though, attention has being shifted from the use of chemical preservative that increase environmental pollution and injure the workers. Besides, it has been duly observed that there are greater potentials in the use of plant and oil extractives as natural preservatives as many components of their extracts are very toxic to organisms imparting decay resistance to wood (Osman et al., 2007 Amienyo et al., 2007, Kirker et al., 2013, Tascioglu et al., 2013, Adegoke et al., 2015, Brocco et al., 2017, Okanlawon et al., 2020). Among all woodfeeding organisms (insects), termites cause the most serious damage being an integral component of various ecosystems in Africa (Nkunika, 2010).They are responsible for considerable damage in building structures, attack growing trees, synthetic products, wool and agricultural crops (Malaka, 1996). The oil from seeds of tree species to produce biodegradable chemical capable of prolonging service life of nondurable wood is a promising approach to wood preservation. An example of species with such potential is Azadirachta indica. This study is therefore aimed at evaluating the effectiveness of seed oil from A. indica (Neem) against wood decaying termite using selected tropical wood species with a view to promoting environmental friendly preservatives.

\section{MATERIALS AND METHODS}

Seed collection and preparation: Azadirachta indica seeds were collected from Polytechnic Ibadan, Nigeria. The Seed of $A$. indica was peeled to removed endocarp and oven dried at $103 \pm 2{ }^{\circ} \mathrm{C}$ to reduce its moisture content. The seeds were later ground with a laboratory electric blender.

Extraction of A. indica seed oil: Two hundred $(200 \mathrm{ml})$ of n-Hexane was poured into round bottom flask. $30 \mathrm{~g}$ of the sample was placed in the thimble and was inserted in the centre of the extractor. The soxhlet was heated at $65^{\circ} \mathrm{C}$. When the solvent was boiling, the vapour rose through the vertical tube into the condenser at the top. The liquid condensate drips into the filter paper thimble in the centre, which contains the solid sample to be extracted. The extract seeps through the pores of the thimble and fills the siphon 
tube, where it flows back down into the round bottom flask. This was allowed to continue for $6 \mathrm{~h}$. It was then removed from the tube, allowed to cooled and weighed to determine the amount of oil extracted (Adegoke et al., 2015).

Phytochemical screening of $A$. indica seed oil: Phytochemical screening of $A$. indica seed oil was done following the standard procedure by the method of (Brain and Turner, 1976). The seeds were ground and subjected to phytochemical screening for the presence and amount of alkaloids, saponins, tannins, steroids, terpenoids, flavonoids, and phenolic.

Preparation and treatment of wood test block: The wood samples of Gmelina arborea and Triplochiton scleroxylon were obtained from tree samples within Federal College of Forestry, Ibadan. The wood samples were planed and dimensioned into $20 \mathrm{x} 20 \mathrm{x}$ $60 \mathrm{~mm}$ (longitudinal $\mathrm{x}$ radial $\mathrm{x}$ tangential directions).They were labeled, weighed (initial weight- $\mathrm{T}_{1}$ ) and dried in an oven at a temperature of $103 \pm 2{ }^{\circ} \mathrm{C}$ until excess moisture content was removed.

The methods adopted for wood treatment were brushing, dipping and soaking method. Small portion of the oil was poured into $600 \mathrm{ml}$ of beaker and a soft brush was used to apply the oil. For dipping method, portion of the oil was poured into $600 \mathrm{ml}$ of beaker, the wood sample was dipped and removed immediately while the wood sample was completely immersed for $72 \mathrm{~h}$ in order to achieve soaking. Afterward, the wood test blocks were drained and reweighed to determine the percentage absorption using equation 1.

$$
\% A R=\frac{T_{3}-T_{2}}{T_{2}} X 100 \ldots(1)
$$

$\% \mathrm{AR}=$ Percentage Absorption, $\mathrm{T}_{3}=$ Weight after soaking, $\mathrm{T}_{2}=$ Oven-dried weight

The treated wood test samples were placed on a wire mesh and conditioned under room temperature in the laboratory for $72 \mathrm{~h}$, the wood samples were withdrawn and weighed $\left(\mathrm{T}_{4}\right)$

Weight loss: The percentage weight loss of each wood sample due to termites attack was calculated using the formula below

$$
\% W L=\frac{T_{4}-T_{3}}{T_{3}} X 100 \ldots \ldots
$$

$\% \mathrm{WL}=$ Percentage weight loss, $\mathrm{T}_{3}=$ Weight after conditioning, $\mathrm{T}_{4}=$ Weight after exposure to fungi
Data analysis: Analysis of variance (ANOVA) was used for significant different between methods of application and wood species. A comparison of the means was conducted employing Duncan Multiple Range Test (DMRT) to identify which groups were significantly different at $\alpha_{0.05}$ when the ANOVA indicated a significant difference among methods of application and wood species.

\section{RESULTS AND DISCUSSION}

Phytochemical Screening: As presented in Table 1, the results of qualitative and quantitative phytochemical analysis of $A$. indica seed oil. The results revealed that seed extracts of medicinal plant offers a source of naturally occurring chemicals like alkaloids, flavonoids, saponins, steroids, tannins, terpenoids, and phenolic with 2141.7, 1418.3, 43.3, 218.3, 975.0, $826.7 \mathrm{mg} / 100 \mathrm{~g}$ and $62 \mathrm{GAE} / \mathrm{g}$. respectively. Mahmood et al., (2008) affirmed that these compounds also serve to protect the plant against infections by microorganisms, predations by insects and herbivores, while their odor and flavor are responsible for their pigments. More importantly, scholars (Haller, 1990, Mossini et al., 1993, Sofowora, 1993, Allameh et al., 2002, Kumar et al., 2018) reported the biological activity of the neem crude extracts and their different part such as leaf, bark, root, seed, etc have been used as traditional medicine for the treatment of various diseases ranging from the teeth decay, ulcers, swollen liver, malaria, among other.

Besides, the phytochemicals like alkaloids, flavonoids and saponins are antibiotic of plants thus act as the defensive mechanism of plants against different pathogens (Kumar et al., 2009 and Kumar et al., 2018).

Table 1. Qualitative and quantitative phytochemical screening of

\begin{tabular}{lll}
\multicolumn{3}{c}{ A. indica seed oil. } \\
\hline $\begin{array}{l}\text { Phytochemical } \\
\text { Composition }\end{array}$ & Qualitative & $\begin{array}{l}\text { Quantitative } \\
\text { Value }(\mathbf{m g} / \mathbf{1 0 0 g})\end{array}$ \\
\hline Alkaloids & + & 2141.7 \\
Flavonoids & + & 1418.3 \\
Saponins & + & 43.3 \\
Steroids & + & 218.3 \\
Tannins & + & 975.0 \\
Terpenoids & + & 826.7 \\
Phenols & + & $62.0 \mathrm{GAE} / \mathrm{g}$ \\
\hline
\end{tabular}

Percentage absorption of wood samples: The Figure 1 shows the effect of application method on percentage absorption of $G$. arborea and $T$. scleroxylon wood in that soaking method recorded the highest absorption percentage with 11.20 and $43.88 \%$ for G. arborea and T. scleroxylon respectively while the lowest was at brushing for $G$. arborea and T. scleroxylon for dipping and brushing with $8.2,38.5$ and $39 \%$ respectively. There were significant variations $(\mathrm{p}<0.05)$ in the 
methods of application, and interaction between periods of method and wood species but not for wood species as revealed in Table 2. The absorption increased with different application methods however, absorption is proportional to the treatment time in soaking (Owoyemi et al., 2011; Adegoke et al., 2015 and Okanlawon et al., 2020). The absorption of preservatives by many wood species differs and this can be attributed to wood structure. Beside, penetration ability, viscosity of preservative and chemical composition of the preservative can also contribute to the absorption of preservative.

Table 2: F-calculated of ANOVA table for percentage absorption and weight loss

\begin{tabular}{lll}
\hline Source of variance & $\begin{array}{l}\text { Absorption } \\
(\%)\end{array}$ & $\begin{array}{l}\text { Weight } \\
\text { Loss }(\%)\end{array}$ \\
\hline $\begin{array}{l}\text { Methods of } \\
\text { application (MA) }\end{array}$ & $191.55^{*}$ & $464.62^{*}$ \\
Wood species (WS) & $636.97^{*}$ & $0.00 \mathrm{~ns}$ \\
MA*WS & $73.19^{*}$ & $3.36 \mathrm{~ns}$ \\
\hline *-Significant $(P \leq 0.05) ;$ & $n s-$ No significant $(P>0.05)$
\end{tabular}

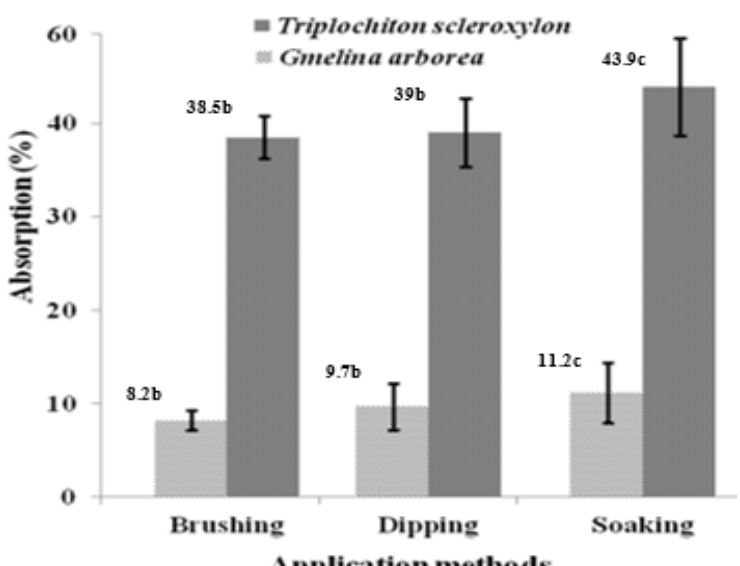

Fig 1: Effect of application methods on percentage absorption of G. Arborea and T. Scleroxylon wood. Mean values with the same alphabet in each bar are not significantly different $(p \leq 0.05)$ using duncan multiple range test:

Percentage weight loss to termite: The percentage weight loss of G. arborea and T. Scleroxylon wood to termite explain the effect of $A$. indica seed oil. It was also noticed that untreated wood block had percentage weight loss of 56.50 and $61.58 \%$ while lowest weight loss were recorded for soaking method at 3.89 and $4.66 \%$ for $G$. arborea and T. scleroxylon wood respectively as revealed in Figure 2. The Table 2 shows the significant differences that exist in application methods of $A$. indica seed oil to after weight loss to termite attack $(\mathrm{p}<0.05)$. In respect to the wood block considered for this study, the extent of weight loss indicated the antimicrobial properties of the need seed oil may be due to the availability of phytochemicals (alkaloids, flavonoids, tannins and saponins) which promote antimicrobial activity
(Akujobi et al., 2004, Ogbulie et al., 2007, Mohammed et al., 2012). Mazhar et al., (2013) also affirmed that the seed extracts of medicinal plant do offers a source of naturally occurring chemicals that could be used as anti-termite. However, number of studies also has also proved the effectiveness of seed oil originated from plant to be more effective (Osman et al., 2007 Amienyoet al., 2007, Tascioglu et al., 2013, Adegoke et al., 2015, Brocco et al., 2017, Okanlawon et al., 2020). Convincingly, the phytochemical constituents present in the seed oil are very toxic and active against wood termite.

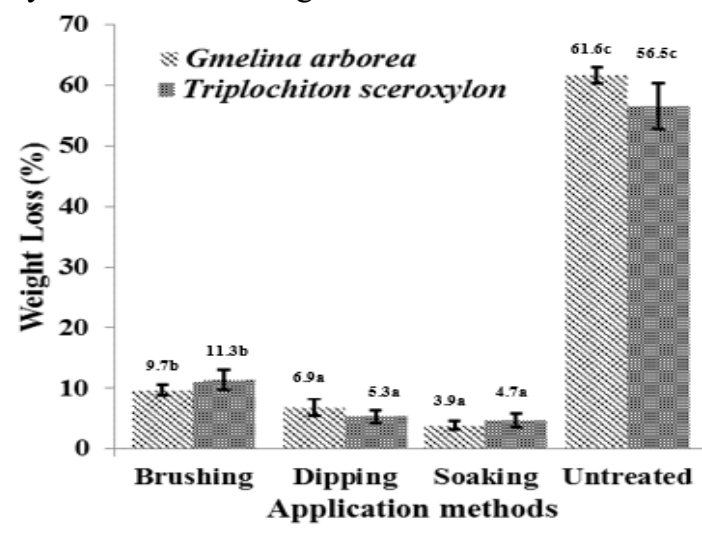

Fig 2: Effect of application methods on percentage weight loss of G. arborea and T. Scleroxylon wood. Mean values with the same alphabet in each bar are not significantly different $(\mathrm{p} \leq 0.05)$ using duncan multiple range test.

Conclusion: The antimicrobial properties of the crude leaf extract of $A$. indica seed oil may be due to the availability of phytochemicals which promote antimicrobial activity. Hence, these findings provided preliminary scientific information on the potential of the seed oil to control termite. However, $A$. indica seed oil is completely feasible to be use as alternative chemical based preservative. Consequently, all the methods of application proved to be effective over the untreated wood while soaking method is most preferred.

\section{REFERENCES}

Adegoke, O; Okanlawon, F; Ajala O (2020). Efficacy Of Pyrolytic Oil Obtained from Wood Sawdust against Wood Decay Subterranean Termite. PRO LIGNO. 16(1):28-35

Adegoke, OA; Ajala, OO; Alamu, AJ (2015). Antitermite effectiveness of Calophyllum inophyllum Linn. Seed oil on selected tropical wood species. XIV World Forestry Congress, Durban, South Africa. September 2015. pp 7 11.

Akujobi, C; Anyawu, BN; Onyeze, C; Ibekwe O. (2004). Antibacterial activities and preliminary screening of four medical plants J. Applied Sci. 7 (3), 4328-4338. 
Allameh, AMR; Abyaneh, MA; Shams, MB; Rezaee, O; Jaimand, K (2002). Effects of neem leaf extract on production of aflatoxins and activities of fatty acid synthetase, isocitrate dehydrogenase and glutathionestransferase in Aspergillus parasiticus. Mycopathologia, 54:79-84.

Amienyo, CA; Ataga, AE. (2007). Use of Indigenous Plant Extracts for the Protection of Mechanically Injured Sweet Potato (Ipomoea batatus) tubers. Sci. Res. Essay. 2(5):167-170.

Brain, KR; Turner, TD (1976). The Practical Evaluation of Phytopharmaceutical, (1st Edition, Britol Wright Scientechnia, pp 105.

Brocco, VF; Paes, JB, da Costa, LG; Brazolin, S; Chaves Arantes, MD (2017). Potential of teak heartwood extracts as a natural wood preservative,J. Cleaner Prod.142 (4):2093-2099.

EL-Mahmood, AM; Doughari, JH; Ladan, N (2008). Antimicrobial screening of stem bark extracts of Vitellaria paradoxa against some enteric pathogenic microorganisms. Afr. J Pharm. Pharmacol. 2 (5):089094.

Haller, JS (1990). A drug for all seasons. Medical and Pharmological history of Aloe vera. Bulletin in New York Academy of Medicine.66: 467-659.

Hill, RA (1985). Terpenoids. In Thomson RH, (ed). Chemistry of Natural Products, Blackie Academic and Professional. London. 106-134.

Kartal, SN; Yoshimura, T; Imamura, Y (2004). Decay and termite resistance of boron-treated and chemically modified wood by in-situ co-polymerization of all glyucidyl ether (AGE) with methyl methacrylate (MMA) Int. Biodeterior. Biodegration 53 (2): 111-17.

Kirker, GT; Blodgett, AB; Arango, RA; Lebow, PK; Clausen, CA. (2013). The role of extractives in naturally durable wood species. Int. Biodeterior. Biodegrad. 82:53-58

Kumar, AG; Wu, CJ; Kumar, BJ; Ha, DC (2009). Antioxidant activity and quantitative estimation of azadirachtin and nimbin in Azadirachta indica A. Juss grown in foothills of Nepal, Afr. J. Biot. 8(13): 30843091.

Kumar, R; Sharma S; Devi, L (2018). Investigation of Total Phenolic, Flavonoid Contents and Antioxidant Activity from Extracts of Azadirachta indica of Bundelkhand Region. Int. J. Life. Sci. Scienti. Res., 4(4): 1925-1933.

Malaka, SLO (1996). “Termites in West Africa, ” University of Lagos Press, Lagos, Nigeria. Pp. 165.
Mazhar, A; Muhammad, S., Munawar, I; Fozia, A; Sumaira, S; Sohail, A; Tajnees, P (2013). Antitermitic Activity and Phytochemical Analysis of Fifteen Medicinal Plant Seeds. J. Med. Plants Res 7(22): 1608- 1617.

Mazhar, A; Muhammad, S; Munawar, I; Fozia, A; Sumaira, S; Sohail, A; Tajnees, P (2013). Antitermitic Activity and Phytochemical Analysis of Fifteen Medicinal Plant Seeds. J. Med. Plants Res. 7(22): 1608- 1617.

Mohammed, M; Pateh, UU; Maika, NO; Lami, L; Abdulwaliy, I (2012). Phytochemical and Antimicrobial activities of the leaf extract of Stachytarpheta Angustifolia (Mill) Vahl verbenaceae. Inter. J. Sci. Tech. 2(10)

Mossini, SA; Oliveira, KP; Kemmelmeier, C (2004). Inhibition of patulin production by penicullium expansun culture with neem (Azadirachta indica) leaf extracts. Basic Microbiol. 44: 106-113.

Nkunika, POY; Ahmed (Shiday), BM; Sileshi, GW; French, JRJ; Nyeko, P; Jain, S (2010). Termite taxonomy and distribution with particular reference to climate change in Africa. TheInternational Research Group on wood preservation 41st Annual Meeting, Biarritz, France. pp 1-17.

Ogbulie, JN; Ogueke, CC; Okoli, L; O; Anyawu, BN (2007). Antibacterial activities and toxicological potential of crude ethanolic extracts of Euphorbia hirta. Afr. J. Biotechnol. 6(13): 1544-1548.

Okanlawon, FB; Olaoye, KO (2020). Bio Preservative Potential of Ocimum basilicum L. Leaf Extract on Triplochiton scleroxylon (K. Schum) and Ceiba pentandra (L.) Gaertn. Wood against Termite Attack. European Sci. J. 16(9):76-81

Osman, G; Ramazan M; Emin MD; Ertan, O; Melda, C; Ferah Y (2007). Introduction and evaluation of the wood preservative potentials of the poisonous Sternbergia candidum extracts. Afr. J. Biotechnol. 6(8): 982-986.

Owoyemi, JM; Kayode, J; Olaniran, SO (2011). Evaluation of the resistance of Gmelina arborea wood treated creosote oil and liquid cashew nut shell to subterranean termites' attack. PRO LINGO 7(2), 3-12.

Sofowora, A (1993). Medicinal Plants and Traditional Medicine in African Spectrum Book Ltd. University of Ife Press Nigeria. pp.119.

Tascioglu, C; Yalcin, M, Sen, S; Akcay, C (2013). Antifungal properties of some plant extracts used as wood preservatives. Int. Biodeterior. Biodegr. 85:23-28. 